\title{
The "Danger" From Foreign Ownership of U.S. Farmland
}

\author{
CLIFTON B. LUTTRELL
}

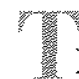

HERE has been renewed concern in recent months about purchases by foreign citizens of farmland in the United States. In addition to numerous newspaper and magazine articles on such purchases, the U.S. Congress and a number of state legislatures have become concerned with the subject. ${ }^{1}$ Foreign ownership of farmland has been restricted in 20 states, and more recently the U.S. Congress approved legislation that would require foreign investors to report all purchases or long-term leases of American farmland to the Secretary of Agriculture.

Most of the objections to alien ownership are based on emotional factors, which, although having impor-

\footnotetext{
1Examples of such articles include: Jerome P. Curry, "Banks Shield Alien Owners of Farm Land" St. Louis Post-Dispatch, May 3, 1978, and "Foreign Investors Making Purchases of Illnois Farm Land," St. Louis Post-Dispatch, April 30, 1978; E. W. Kieckhefer, "Middle-Size Operation Aid Urged," Memphis Commercial Appeal, May I4, 1978 and "Foreign Ownership of Farmland Topic of Debate," Memphis Commercial Appeal, June 25, 1978; Wendell Cochran, "Limit Urged on Foreign-Owned State Latad, Kansas City Times, Jamuary 14 1978; Jody Cox, "Foreign Buyers May Be Shut off from Famland, Columbia Missoutian, January 21, 1978; and "Senate, House Split on Farm Land Ownership Bill" Colum bia Missourian, Tebruary 8, 1978; "Alien Land Issue Okayed," Daily Capital News, March I, 1978; "Famland Issne Put Off," Daily Capital News, February 21, 1978; James F. Wolfe, "Capitol Commentary," Joplin Globe, March 20, 1978; Don Keough, "Capitol Conment," Columbia Tribune, February 19 1978; "Fannland Bill Approved," Daily Capital News, April 13, 1978; Jody Cox, "Assembly OKs Bill Limiting Foreign Owned Farmland," Columbia Missourian, April 14, 1978; Ellen F. Harris, "A Threat to Missouri," St. Louis GlobeDemocrat. February 6, 1978; and Vincent Coppola with Pamela Ellis Simns, "Farming: Pastaville, III," Newsweek (May 22, 1978), pp. 55-6.
}

tant economic implications, are in themselves difficult to analyze. This article examines some of the underlying implications of the objections, demonstrates the conflict between economic forces and the widely held utopian view of agriculture that farms should be largely owned by the operator, and analyzes some important economic factors implicit in the arguments against foreign ownership.

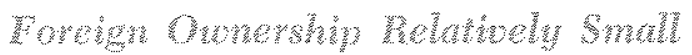

Despite the great amount of discussion of the topic, the quantity of farmland in the United States owned by foreigners is relatively small - well less than one percent of the total acreage. On the basis of a sturvey by the U.S. Department of Commerce at the end of 1974 , only about 4.9 million acres of land in the U.S. were owned by groups in which the foreign-owned equity accounted for 10 percent or more of the total (Table I). While some small tracts of land were

Legislative action has been taken in several states limiting or prohibiting the ownership of farmland by citizers of foreign countries. In late 1975 sach restrictions were smmmarized as follows: General prohibition of alien ownership - 6 states; substantial restrictions on such ownership - 6 states; minor restrictions - 8 states; and no restriction - 30 states. It is not certain that any of these laws are constitutional; some may be in violation of United States treaty obligations, and in other instances the restrictions may be avoided by the use of fidnciaries. Nevertheless, legislative activity designed to restrict foreign ownership of famland has contined in a number of states where no restrictions exist or the restrictions are minimal.

Page 2 
not reported, these data nevertheless greatly overstate the extent of foreign ownership in farmland since much of the land owned by foreign-affiliated groups consists of forest land, land holdings for petroleum production, and land for other industrial purposes. Ownership of farmland by foreign-affiliated groups at that time was estimated to be only one million acres or about 0.1 percent of the total U.S. farmland. ${ }^{2}$ Foreign purchases may have increased since this survey was made, but if doubled, such holdings would total no more than 0.2 percent of the total.

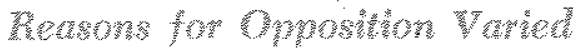

Reasons given for the opposition to foreign ownership of farmland have varied over the years. During the first wave of anti-foreign ownership legislation in the 1880 s, especially during the debates on the Alien Land Act of 1887, a major objection was the fear that American farmers would become "servants of distant masters uncomprehending the rights and needs of Americans." Objections to alien ownership tended to wane in the $1890 \mathrm{~s}$, but with the rising Japanese investment in land on the West Coast, a second wave of restrictions began in California in 1913 with racial prejudice playing a major role.

The California law, which prohibited land ownership by aliens ineligible for citizenship, became the model for anti-Japanese legislation throughout the West and as far east as Delaware. Interest in such restrictions slackened during the Great Depression and World War II, and most of the restrictions were declared unconstitutional in a 1948 Supreme Court decision which struck down the "eligibility for citizenship" test. ${ }^{4}$

The Illinois House Agricultural Committee, in April 1978 , voted to recommend passage of a bill which would prohibit the purchase of Mllinois land by nonresident aliens and big business organizations after June 1979. In mid-April of 1978 following a relatively long debate, the Missonri General Assembly enacted a bill which essentially banned foreign ownership of farmland in the state. See Alice Bomner, "Disclosure of Foreign Farn Holdings Booked," Washington Post, August 9, 1978; and "House Votes to Require Aliens to List Fanmland, The Wall Street Joumal, September 26, 1978; U.S. Department of Commerce, Repont to Congress: Foreign Direct Investment in the United States, Vol. 2: Appendices, October 1975, pp. XI 12,13, and XI 30-43; "Foreign Investors Making Purchases of fllinois Farm Land,"St. Louis Post-Dispatch; and "Assembly OKs Bill Limiting ForeignOwned Farmand," Columbia Missourian.

2U.S. Department of Commerce, Report to the Congress: Foreign Direct Investment in the United States, Vol. 1, p. 184.

3Terry L. Anderson, "A Survey of Alien Land Investment in the United States, Colonial 'Times to Present," U.S. Depart ment of Commerce, Report to the Congress: Foreign Direct Investment in the United States, Vol. 8, p. L 14.

4lbid., pp. L 13-18.

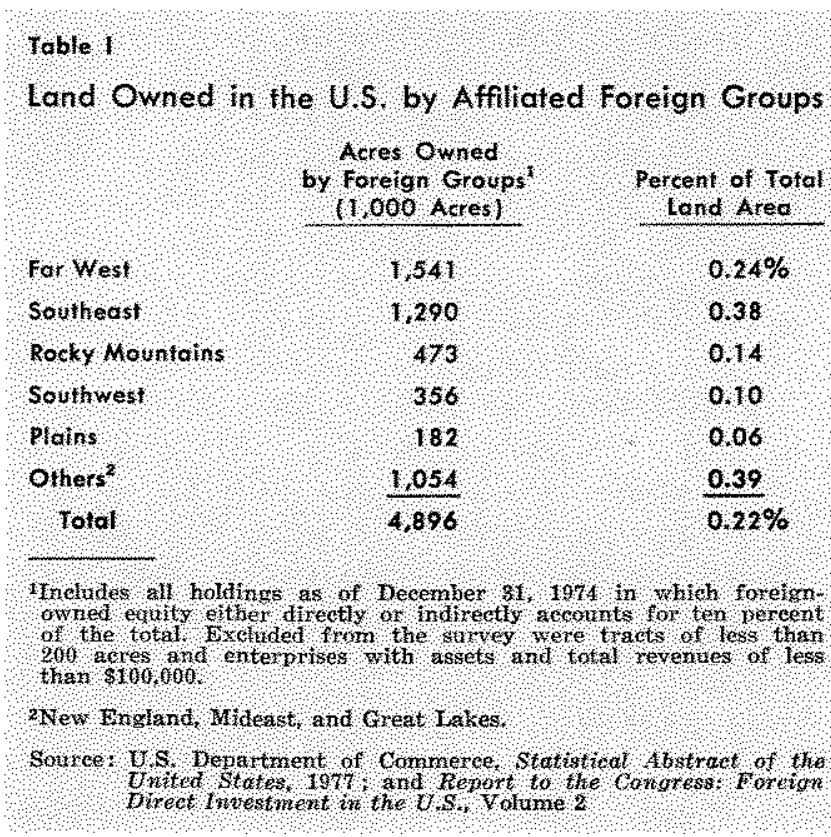

The reasons given for opposing such ownership during the recent wave of restrictive legislation may be summarized as follows:

1. Fear for the loss of local control and concem for the survival of farming communities

2. The possibility of a feudal-type system of absentee landholdings arising from such ownership

3. Investment from abroad in U.S, farmland causing land prices to rise beyond the holding potential of local farm operators and thereby threatening the traditional family-type farm

4. The possibility of foreign ownership causing higher rents, reducing U.S. soil fertility and food supplies, and impeding the effectiveness of the nation's food production policies ${ }^{\bar{x}}$

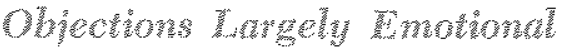

Included among the emotional objections to foreign ownership of farmland are the fear of the loss of local control of rural communities, a feudal-like system of land control, a system of absentee landlords, and the demise of the family farm. While people's fear of these assumed impacts is an important factor affecting legislation, an analysis of historic trends indicates that there is little basis for most of the fear expressed.

\footnotetext{
5Crág Currie, Michael Boehlie, Neil Harl, and Duane Harris, "Foreign Investment in Iowa Farmland," Report to Congress, Vol. 8, pp. L 31, 45, and 47; Curry, "Foreign Investors Makity Purchases of Illinois Farm Land;" Harris, "A Threat to Missouri;" Cochran, "Limit Urged on Foreign-Owned State Land," and Bonner, "Disclosure of Foreign Farm Holdings Booked."
} 
For example, based on experience in recent years, there is little chance of most communities losing local control of public offices or other local affairs as a result of foreign land purchases. The quantity of farmland placed on the market in any community in any one year is a relatively small proportion of the total. Hence, the possibility of a large number of purchases by foreigners in any one community within a year or two is quite remote. Also, only a small percent of aliens who purchase land are likely to emigrate to the rural communities. In those cases of recent purchases, the land continues to be operated by American farmers and the land-use pattern remains unchanged; consequently, there is little likelihood of a change in local control as a result of alien land purchases. ${ }^{8}$

Similarly, the return of a feudal-like system of landholding is remote. The feudal system of landholding was a system in which a legal monopoly was maintained on the land and the peasantry by hereditary landlords. Ownership of these monopoly rights could be maintained only in the absence of a market for land and labor. Once commercial enterprise and urban labor markets were developed, the serfs obtained freedom from their landlord masters in Western Europe, and a yeoman class of landholders evolved. Free labor and land markets are thus the antithesis of the feudal system. With such markets each worker has numerous opportunities to choose alternative occupations and employers. Hence, there is no necessity for a worker to become subservient to a landlord master.

The association of the demise of the family farm with foreign investment in farmland is likewise largely emotional. The family-farm concept represents a long-standing utopian view of the idealized structure of agriculture. The proponents of the family-farm concept envisage a nation of owner-operated farms in which each fledgling farmer eventually owns his farm free of debt. ${ }^{7}$ An objection to foreign owner-

"See Currie, et. al, "Foreign Investment in Iowa Farmland," p. L 47 .

This simple concept of agriculture has been a dominant feature of farm policy research and farm policy. Professor Schic kele stated, "From the days of Jefferson to the present, the ideal of our farm lands being owned and operated by independent, prosperous farm fanilies has dominated people's thinking and found expression in a rather consistent series of land-setzlement and tenmre programs." See Rainer Schickele, Agricultural Policy: Farm Programs and National Welfare (New York: McGraw-Hill Book Company, Inc., 1954), p. 326 In 1923 the Department of Agriculture reported, " . . farm ownership by the farmer has come to be regarded as normal and tenancy (renting of farmland) abnomal. See U.S. De. partment of Agriculture "Fam Ownership and Tenancy," Agricultural Yearbook, 1923 , p. 507. The "evils" of farm ship associated with the family-farm ideal is the fear that foreign investments in land will drive the prices up beyond the bidding potential of local people. Hence, the fear that the family-farm structure of agriculture will be weakened by foreigners bidding up land prices is a major factor in the objections to their ownership of farmland.

Family-farm proponents are not opposed to some outside ownership of farmland, but such ownership was expected to be of a transitory nature. The extent of outside ownership desired was depicted in the socalled "agricultural ladder" which shows the individual climbing rungs from boy apprentice to hired hand, to tenant farmer, to mortgaged owner, to owner free of debt, and ultimately to the independent position of a retired landlord. ${ }^{8}$ Some tenancy and landlordship was recognized as an essential feature in the progress of the fledgling farmer toward owneroperator status. However, the "predatory instincts" of capitalists were to be held in check. The maintenance of relatively low farmland prices so as to ease the climb up the ladder from tenant to self-employed proprietor was a key factor in the perpetuation of the family-farm structure. ${ }^{10}$

tenancy are often alleged but seldom discussed in agricultural research publications. A. H. Benton in his study on land rental practices stated, "No effort is made to go into the details of the evils of tenancy, to discuss its causes, or to sug. gest a remedy." See Leonard A. Salter, Ir., A Critical Retiew of Research in Land Economics (Minneapolis: The University of Minnesota Press, 1948), p. 181.

The family farm was strongly endorsed by the Secretary of Agriculture in 1951. He reported: "The family farm system leads to agricultural progress and good community life. It builds in the family members attitudes of self-reliance, social responsibility, individual initiative, tolerance, and self-government - the attitudes that make for a sound democracy and the human qualities that have done so much to make our Nation great." See U.S. Department of Agriculture, Charles F. Brantian, Secretary of Agriculture, "Preserving the Farnily Farm," Family Farm Policy Review, 1951, p. 1.

sHenry C. and Anne Dewees Taylor, The Story of Agricultural Economics in the United States 1840-1932 (Ames: The Iowa State College Press, 1952), pp. 820-29.

9Professor Wehrwein argued that American land policy should be ". . . not to go beyond a normal percentage of tenant farming." Probably this percentage would be that amount of tenancy needed to provide the proper step toward ownership for the tenant and to bridge the gap for the retreating (retiring) farmer between active work on his fam and complete retirement. See G. S. Wehrwein, "Place of Tenancy in a System of Fammland Tenure," Journal of Land and Public Utility Economics, January 1925, as reported in Taylor, The Story of Agricultural Economics in the United States, pp. 828-29.

10Professor Spilman in discussing the ladder in 1918 stated:

"In helping tenants to buy farms, it would be legitimate to limit the purchase price, say to a specified number of years' rent. This would tend to prevent farm land from rising to such prices that men can not hope to pay for their farms during their working life." See W. J. Spillman, "The Agricultural Ladder" The American Economic Review: Supplement (March 1919), pp. 170-79, as reported in Taylor, The Story of Agricultural Economics in the United States, p. 824.

\section{Page 4}




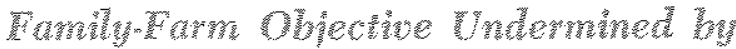 Domestic Thonomic roroes, Wot Fotergat

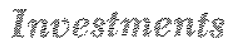

The major threat to the family farm as idealized by much of the public is domestic economic forces rather than foreign land investments. Because of the greatly increased efficiency in production, farmers can now manage and farm more acres than formerly. Based on data of the U.S. Department of Agriculture, local people within the county purchased 78 percent of farmland acreage sold in the nation in 1977 (Table II). Hence, it is usually the farmer next door seeking more land to enlarge his farm or others in the com" munity looking for a good investment who purchase the farmland.

The forces contributing to a changed structure of agriculture are the result of new technologies in farm production. Improved machinery, equipment, seed, power, fertilizer and other chemicals have resulted in a sharp increase in output per farm worker, a rapid decline in the number of farm workers, an increase in the average size of farms, a decline in the number of farms and a major increase in capitalization per farm.

The North-Central Regional Committee on Land Tenure Research in 1944 proposed a number of public policies consistent with the agricultural ladder approach to family farming and relatively low farmland prices. Included among its recommendations were: (1) appropriate measures be taken to discourage corporations from purchasing land for farming purposes; (2) that land taken in satisfaction for debt be returned to farm family ownership as promptly as practicable; (3) consideration be given to levying graduated land taxes to discourage large-scale absentee ownership of farms; (4) make an active effort to hold more Midwest farms under continuous ownership and operation by succeeding generations of the same family; and (5) take appropriate measures to discourage the inflation of land prices including persuading prospective farm owners to postpone buying farms where land prices have risen unduly, inducing both farmers and nonfarmers to use their increased wartime earnings to purchase government bonds, levying a progressive tax on the profits from the resale of real estate, and urging farm mortgage lenders to make loans on the basis of long-time eaming capacity rather than on the basis of temporary prices. See lmproving Farm Tenure in the Midwest, University of Ilinois Agricultural Experiment Station, Bulletin 502, 1944, pp. 143-54.

The structure of agriculture approached the family farm ideal in the 1800 s when land was relatively cheap and farming was largely self-sufficient. In 1910 more than half of the nation's farms and 52.9 percent of the land in farms was operated by owners. Farm debt was relatively low, indicating that a large portion of the ewner-operators may have been free of debt. Total real estate farm debt, for example, was $\$ 3.2$ billion, only about three-fourths the total net income to farm operators. In contrast, by 1964 only 28.7 percent of the farmland in the nation was operated by owneroperators, and famm real estate debt was double the net income to operators. In 1977 farm real estate debt totaled $\$ 56.0$ billion or three times the net income to operators.

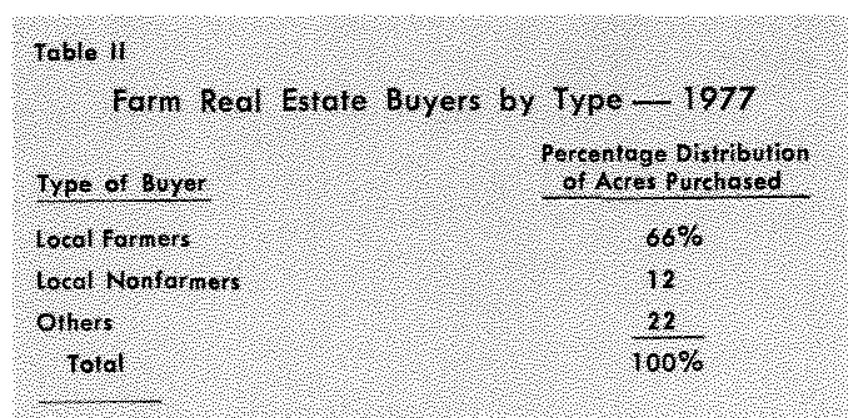

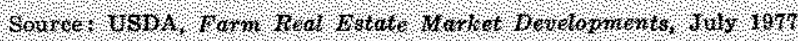

Some measures of these changes during the current century are shown in Tables III and IV. Farm production per man-hour has increased more than tenfold since 1910 and the rate of increase has accelerated since 1940. For example, during each of the decades, 1950-60 and 1960-70, production per manhour almost doubled. The overall number of manhours used in farm work in 1976 was 5.1 billion, or less than one-fourth the amount used in 1910. During the same period the number of farm workers declined from 13.6 million to 4.4 million. The average size of farms has more than doubled since 1910-14, rising from 140 acres to 397 acres; and as indicated in Table $\mathrm{V}$ the more profitable farms are well above average size. During the same period the number of farms declined from 6.4 million to 2.7 million.

The incentive for larger farms is the consequence of a sizable shift in the costs of farming. Prior to the development of labor-saving machinery and other cost-reducing technology, costs per unit of output for the average farm bottomed out at relatively low levels of output per year. With the advent of the

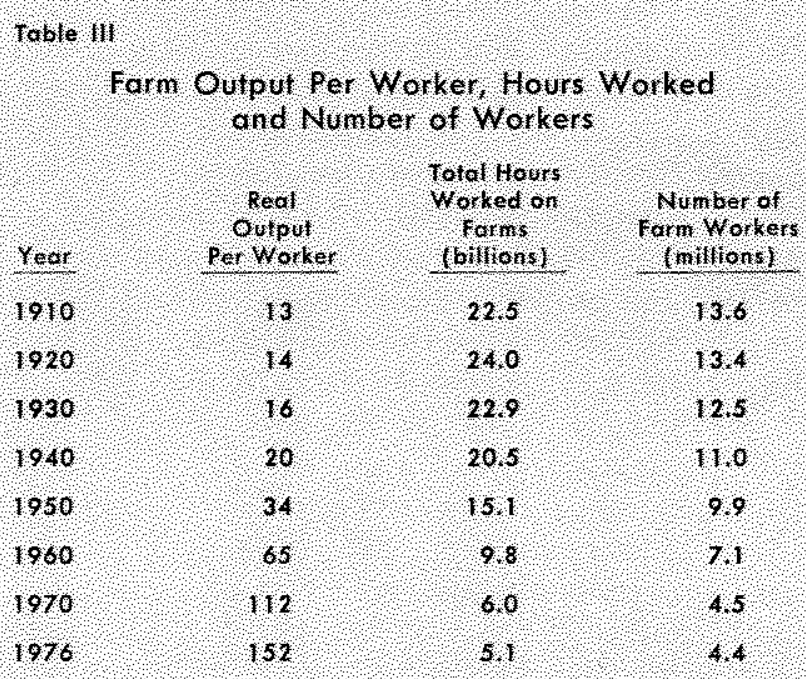

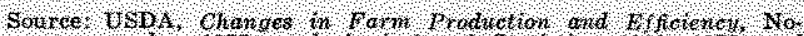
remer 197 ? 
Toble IV

Number of farms and Acreage, Value of Land and Buildings and lncone Ratios Per farm

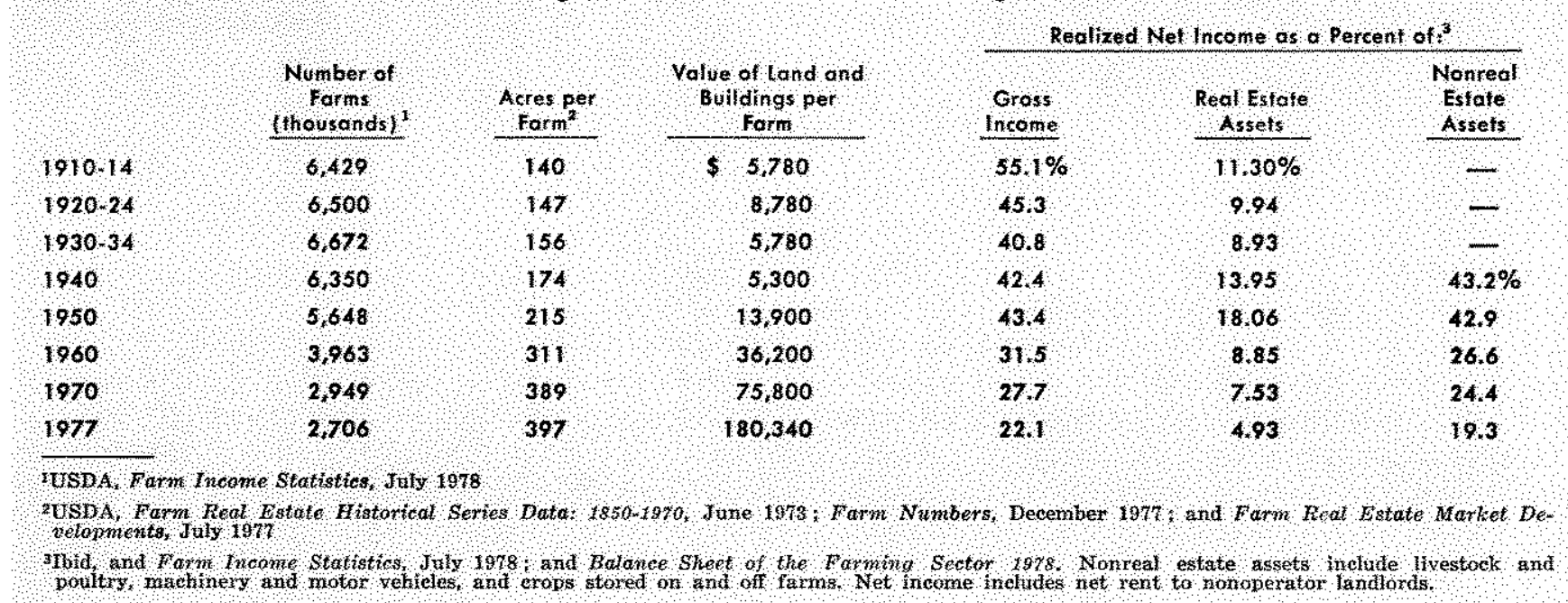

larger machines, average short-run and long-run farm cost curves shifted downward and to the right, resulting in lower per unit costs for larger farms. This shift provided great incentive for each farm operator to obtain additional assets, including farmland, in order to further reduce cost of production.

The larger farms and the rising use of farm machinery have led to a major increase in farm capitalization. The increased acreage and the larger quantity of machinery have both been factors in the rising capital requirements for profitable farming. The average value of land and buildings per farm has risen to more than 30 times its $1910-14$ value. The average value of real estate per farm rose from less than $\$ 6,000$ during the pre-World War I period to more than $\$ 180,000$ in 1977 .

But this is not the whole story. As shown in Table $\mathrm{V}$, the average value of all assets per farm on farms with annual sales of $\$ 100,000$ and over, which sold 53 percent of all farm products in 1976 , was $\$ 1.2$ million. The average value of assets on farms with sales of $\$ 40,000$ and over, which sold 78 percent of all farm products, was $\$ 667,000$. At this level of capitalization and at current income and estate tax rates, an efficient-sized farm can neither be inherited nor acquired debt-free through earnings by most farm families as envisioned in the family-farm concept.

Part of the increase in nominal capitalization reflects a rise in the general

Table $y$

11977 data price level, but much of it reflects the rising productivity of larger farms. The general price level rose about 6 times from the $1910-14$ average to $1976 \mathrm{com}$ pared with the 30 -fold increase in value of real estate assets per farm.

The decline in the net farm income to farm asset ratios indicate that it is increasingly difficult for a farmer to own a farm free of debt during his lifetime. As indicated in Table IV, realized net income to farm operators in 1977 was only 4.9 percent of the value of farm real estate assets. ${ }^{11}$ Such income was only 3.6 percent of the value of all farm assets. In contrast, realized net income averaged about 10

11Realized net income to farm operators is the return to operators for their labor, management, and equity in the farm assets prior to an adjustment for inventory change.

Net Income and Assets Per Farm by Size Group

\begin{tabular}{|c|c|c|c|c|}
\hline Farms with Sales & $\begin{array}{c}\text { Percent } \\
\text { Desfribution } \\
\text { Number of } \\
\text { Farms }\end{array}$ & $\begin{array}{l}\text { Percent } \\
\text { Distribution } \\
\text { Form } \\
\text { Cash } \\
\text { Receipts } \\
\end{array}$ & $\begin{array}{l}\text { Nel Income } \\
\text { Per form }\end{array}$ & $\begin{array}{l}\text { Assets } \\
\text { Per Ferm }\end{array}$ \\
\hline$\$ 100,000$ and over & $5.8 \%$ & $52.6 \%$ & $\$ 38,310$ & $\$ 1,155,287$ \\
\hline$\$ 40,000$ to $\$ 99,999$ & 12.6 & 25.6 & 18,502 & 466,358 \\
\hline$\$ 10,000$ 10 $\$ 39,999$ & 23.4 & 16.5 & 7,530 & 232,995 \\
\hline Less than $\$ 10,000$ & 58.2 & 5.3 & 1,744 & 106,112 \\
\hline All Forms & $100.0 \%$ & $100.0 \%$ & $\$ 7.439$ & $\$ 241,975$ \\
\hline
\end{tabular}

Data as of January 1,197 , based on number of farms implied in the Balance sheet. Source USDA, Batance Sheet of the Farning Sector Hard : and Farm Treome Statistics. 
percent of the value of real estate assets during the period from 1910 to 1950 , and in 1950 exceeded 18 percent of the value of farm real estate. Since then the capitalization of farms has risen rapidly in absolute amounts and relative to net income. Net returns to farm operators for their labor and management, thus, have declined sharply relative to the value of such assets. Hence, the difficulty of one family owning an efficient farm debt-free has increased sharply since 1950.

The tenure pattern outlined in Table VI indicates the trend away from full owner-operators as envisaged in the family-farm concept. Land in farms operated by full owners as a percent of all farmland has generally declined since the turn of the century. The land in such farms exceeded 51 percent of the total in 1900 . It rebounded slightly with the extremely favorable farm commodity prices in the late 1940s, but by 1959 the acreage in farms operated by full owners had declined to 31 percent of the total. The rate of decline has slowed since 1959 , but since the recent data are not comparable the extent of the slowing is unknown.

The family-farm structure of agriculture is thus being slowly transformed not by foreign purchases of farmland but by domestic forces which contribute to the greater efficiency of larger-sized farms than the average farm family desires to acquire in a lifetime.

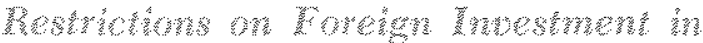

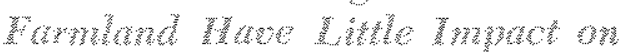

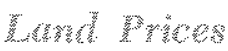

The major economic objective of the restrictive farm ownership legislation - lower land prices - is not likely to be achieved. The capital markets of the nation are well developed and work in a pervasive manner. Injections of new capital tend to permeate all sectors of the market regardless of where the investments are made. How does this come about? The price of any capital good is determined by the stream of net earnings expected from the good. The present value of the capital (V) may be written as $V=\frac{E}{i}$, where $E$ is the permanent annual net earnings and it the interest rate. Hence, after allowance for risks and transactions costs, two capital assets each of which is expected to produce anntal receipts in perpetuity totaling $\$ 5,000$ will, for example, have about the same price (capital value) in the same market. Also, asset prices will move in the same direction in response to changing supply and demand forces in capital markets.

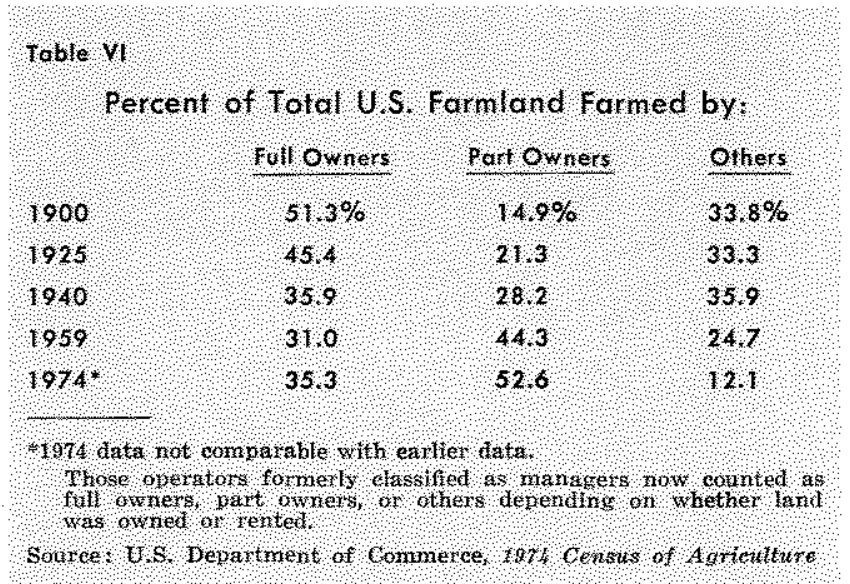

Given the tendency for capital asset values to move in response to changing supply and demand condi. tions, investment decisions by owners of wealth affect farmland values in the following manner. Assuming no change in the expected earnings on farmland, if foreigners bid up farmland prices in the United States, the higher prices will not be maintained very long. The higher land values will reduce the rate of return on land and some owners will observe that their rate is less than the expected rate on other similar forms of wealth. Hence, they will sell land and purchase other assets. This process will continue until the expected rates of return on all similar forms of wealth are again equal.

Similarly, if foreigners increase their investment in General Motors or other U.S. corporate stock and thereby bid up the price, other owners of such stock will find that their expected rate of return is below the expected rate for other similar assets. After allowance for risks and transactions costs, they will thus find it profitable to sell such stocks and invest in other assets, including farmland, where the expected rates of return are higher.

As a consequence of this incentive of all wealth owners to maximize returns, and for the rate of return on all assets having similar risks to move toward equality, foreign investments in the United States will have about the same impact on farmland prices regardless of where such investments are made. Other owners of wealth will tend to offset the imbalances caused by foreign investments in any one sector through the substitution of assets. Hence, it is futile to attempt to restrain land values by restricting foreign investments in land. ${ }^{12}$

\footnotetext{
${ }^{12}$ As indicated earlier, this anatysis assumes that expected earnings on all assets are similar, j.e., have been adjusted for liquidity, transactions costs, and risks.
} 


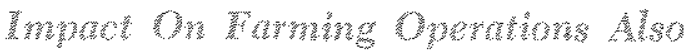 Mring}

The argument that foreign ownership of farmland has an unfavorable impact in terms of higher rents to tenants, higher food prices, lower soil fertility, and disruption of U.S. food producing policies also fails to meet the test of economic analysis. Because all individuals attempt to maximize returns from their wealth, including returns to their own labor, foreign owners of land will have the same incentive to maximize returns on their farmland as domestic landowners. Given similar incentives, cropping rental agreements and land use pattems are not likely to differ much between foreign and domestic owners. If the domestic owner of a tract of land, for example, finds that he can maximize returns by farming the tract in cash crops, the foreign owner will likely reach the same conclusion. This was the case in studies of foreign ownership which have been made to date..$^{13}$

Similarly, foreign owners of farmland have the same incentive to preserve the productivity of the soil as domestic owners. Both have an incentive to maximize the income stream from land holdings into perpetuity, and will have equal incentive to preserve its productivity in order that the income stream will remain intact. Thus, given the same incentives to maximize the earnings stream over time, it is not likely that any major change in the land use or farm production pattern will occur as a result of foreign ownership of farmland.

Even if a major international problem occurred which indicated that U.S. farmland owned by for eigners was being operated for the benefit of another government rather than that of the private owner, this nation has the power to protect its interest without legislation restricting foreign ownership. If necessary, this nation could follow the example of a number of other less-developed nations and confiscate land. However, this should be a last resort as nations which follow such practices are generally considered high-risk investment areas and suffer from a lack of capital. Another means for protecting our nation is to hold such property in trust until the emergency is over.

\footnotetext{
${ }^{13}$ See, for example, Craig Currie, et. al," "Foreign Investment in Iowa Farmland," $\mathrm{p}, \mathrm{L} 47$ and Lloyd $\mathrm{C}$. Irland "Foreign Ownership and Control of U.S. Timberland and Forest $\mathbf{I n}^{*}$ dustry," in Report to the Congress, p. L 69 . In the latter study it was found foreign ownership improved the productivity of forests in Alaska.
}

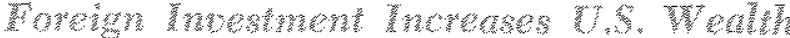

In contrast to policies which restrain foreign investment in the United States, stuch investment should be encouraged. Just as domestic investment adds to the nation's stock of wealth, a major factor in determining the level of production of goods and services, so also does foreign investment in the United States.

While foreign investment in the United States involves interest payment commitments abroad, the new capital adds to production an amount sufficient to more than offset the additional interest cost. Sales of land to foreigners may not show a direct gain in the nation's wealth, but the sales will ultimately lead to an increase in real assets, such as buildings, machinery, land improvements, cars, houses, and bettertrained people. Such investments occur as wealth owners substitute one form of wealth for another. All of these investments generate utility and thereby increase the nation's production. Hence, rather than being suspicious of foreign-owned capital for fear that such investors will gain control of important industries, foreign investment should be welcomed.

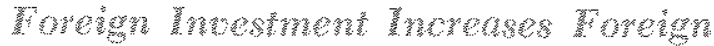

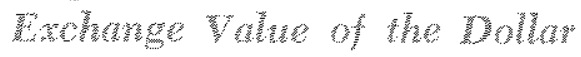

Another feature of foreign investments in the United States is that it results in an increase in the value of the dollar in foreign exchange markets. When this nation imports petroleum and other products, it pays for the goods with dollars. The dollars acquired by foreigners are in. turn used to purchase either capital assets or goods from the United States. If this nation restricts their purchases of capital assets, their demand for dollars will decline relative to the supply, causing the value of the dollar to decline relative to their own currencies. In contrast, with the privilege of investing in relatively attractive United States assets, foreigners have greater demand for dollars, and the dollar will rise in value relative to their own currencies.

Furthermore, the balance available to foreigners to purchase U.S. capital assets is limited without reducing the value of their currencies. During the five years, 1973-77 inclusive, such balances were negative; hence, any purchases of U.S. farmland could only be made as a result of liquidations of other foreign assets in the United States or as an offset to U.S. investments abroad. The largest foreign surplus in this account, $\$ 15.3$ billion in 1977 , was still well below the $\$ 18.4$ billion surplus for the United States 
in 1975. Even if the foreign surplus averaged $\$ 5$ bil lion per year over a ten-year period and the total were invested in U.S. farmland, only about one percent of U.S. farmland could be purchased by foreigners each year.

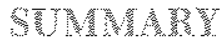

Foreigners own a relatively small amount of farmland, less than one percent of the total. Nevertheless, such ownership has been of major concern in the past year. Legislative action has been taken in a number of states prohibiting or limiting such ownership, and the U.S. Congress has approved legislation which requires reporting of such purchases.

Based on the reported objections, much of the opposition to foreign ownership of land is the result of emotional factors rather than economic forces. The objections are imbedded in utopian views with respect to the structure of agriculture. These views envision U.S. agriculture as consisting almost entirely of small owner-operated family farms. Relatively low farmland prices are necessary for maintaining this ownership pattern. Consequently, family-farm proponents are likewise proponents of a number of public policies designed to reduce farmland prices.

However, trying to keep farmland "cheap" by restrictive legislation is inconsistent with efficient capital markets and modern commercial farming. Expected returns to similar investments tend to be equalized throughout the economy through the cap italization of anticipated returns. As a result, farmland values tend to rise and fall with expected returns on farmland and the rate of capitalization of all forms of capital. Efforts to reduce farmland values through exclusion of foreign purchases are thus not likely to succeed given our well-developed capital markets.

Efforts to limit farm size are also inconsistent with profit motives. Farm technology has resulted in greatly reduced costs for the larger farm units. There fore, adjustments in farm size quickly occur in response to the profit incentive despite the idealistic views as to desired ownership patterns.

The original family-farm structure of agriculture is declining and will likely continue to decline with or without restrictions on foreign purchases of land. The size of land holdings necessary to farm efficiently is already larger than most farm families can acquire in a lifetime through saving alone. Consequently, there is little chance that most farm operators in the next half-century can obtain an efficient-sized farm free of debt within their lifetime. The capital requirements for efficient faming operations are becoming too large for the one-family ownership structure, and such requirements are not appreciably altered by foreign investments in land.

The objection that alien owners will have an unfavorable impact on the type of rental agreement, farming patterns, and food prices is not compatible with basic human incentives. Such owners have the same desire as domestic owners to maximize returns and will tend to carry on farming operations, including tenant relationships, in about the same manner as domestic owners.

In addition, any reduction in foreign investment in the United States will tend to reduce the nation's stock of wealth and its well-being. Our stock of wealth is a major factor in determining our level of production of goods and services. Also, any reduction in foreign investment in the United States reduces the value of the dollar in world trade and increases the price of imported goods for domestic consumers.

Furthermore, there is little chance of foreign interests obtaining control of a large percent of U.S. farmland. The exchange balances available abroad for total investment in the United States are not sufficient to purchase enough farmland to control more than a small percent of U.S. agriculture within the next decade. Also it is most unlikely that the total will be invested in agriculture.

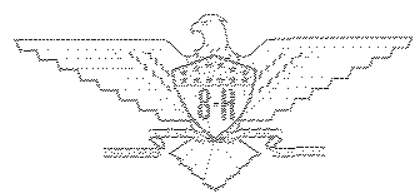

